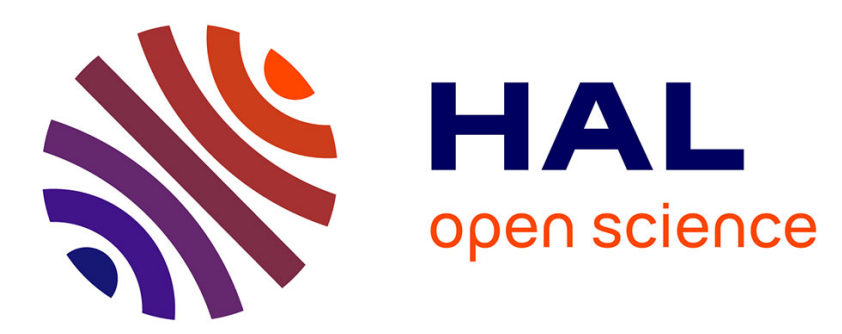

\title{
Synthesis and antiproliferative activities of indolin-2-one derivatives bearing amino acid moieties.
}

Mathieu Sassatelli, Eric Debiton, Bettina Aboab, Michelle Prudhomme, Pascale Moreau

\section{- To cite this version:}

Mathieu Sassatelli, Eric Debiton, Bettina Aboab, Michelle Prudhomme, Pascale Moreau. Synthesis and antiproliferative activities of indolin-2-one derivatives bearing amino acid moieties.. European Journal of Medicinal Chemistry, 2006, 41, pp.709-716. 10.1016/j.ejmech.2006.03.021 . hal-00119556

\section{HAL Id: hal-00119556 https://hal.science/hal-00119556}

Submitted on 2 Mar 2007

HAL is a multi-disciplinary open access archive for the deposit and dissemination of scientific research documents, whether they are published or not. The documents may come from teaching and research institutions in France or abroad, or from public or private research centers.
L'archive ouverte pluridisciplinaire HAL, est destinée au dépôt et à la diffusion de documents scientifiques de niveau recherche, publiés ou non, émanant des établissements d'enseignement et de recherche français ou étrangers, des laboratoires publics ou privés. 


\title{
Synthesis and antiproliferative activities of indolin-2-one derivatives bearing amino acid moieties
}

\author{
Mathieu Sassatelli a, Éric Debiton ${ }^{\mathrm{b}}$, Bettina Aboab ${ }^{\mathrm{a}}$, Michelle Prudhomme ${ }^{\mathrm{a}}$, Pascale Moreau ${ }^{\mathrm{a}, *}$ \\ ${ }^{a}$ Laboratoire SEESIB, université Blaise-Pascal, UMR 6504 du CNRS, 24, avenue des Landais, 63177 Aubière, France \\ ${ }^{\mathrm{b}}$ Laboratoire de pharmacognosie-biotechnologies, UMR Inserm 484, université d'Auvergne, \\ centre Jean-Perrin, rue Montalembert, BP 184, 63005 Clermont-Ferrand cedex, France \\ Received 26 October 2005; received in revised form 16 February 2006; accepted 9 March 2006 \\ Available online 03 May 2006
}

\begin{abstract}
A convenient synthesis of indolin-2-ones substituted in the 3 position by an aminomethylene group bearing different amino acid moieties is described. Their antiproliferative activities were evaluated toward a panel of human solid tumor cell lines (PC 3, DLD-1, MCF-7, M4 Beu, A549, PA 1) and healthy cell lines (a murine fibroblast L929 and a human fibroblast primary culture).
\end{abstract}

(C) 2006 Elsevier SAS. All rights reserved.

Keywords: Indolin-2-ones; Amino acids; Antiproliferative activities

\section{Introduction}

As part of our ongoing studies concerning the preparation of potential antitumor compounds, we were interested in the synthesis of indolin-2-one derivatives [1,2]. 3-Substituted indolin-2-one derivatives are usually known as ATP competitive receptor tyrosine kinase inhibitors. Alterations in receptor tyrosine kinases pathways have been implicated in oncogenic activation, tumor angiogenesis and mitogenic stimulation. Accordingly, receptor tyrosine kinases are attractive targets for the development of novel anticancer agents. Among a large number of receptor tyrosine kinase antagonists, several oxindole derivatives (ATP competitive inhibitors) are in phase I to III clinical development [3-6] (Fig. 1). Moreover, some imidazo[2,1-b]thiazolylmethylene-2-indolinones such as compound $\mathrm{A}$ or indolylmethylene-2-indolinones such as compound $\mathrm{B}$ have been described as $\mathrm{CDK} 1 /$ cyclin $\mathrm{B}$ inhibitors [7] (Fig. 1). Recently, SU9516 (Fig. 1) was described as an ATP competitive CDK inhibitor [8].

The synthesis and biological activities of some aminomethylene-indolin-2-one have already been described in the literature. For example, 3- $N$-methylaminomethylene-indolin-2-

\footnotetext{
* Corresponding author. Tel.: +3347340 79 63; fax: +33473407717.

E-mail address: Pascale.MOREAU@univ-bpclermont.fr (P. Moreau).
}

one was evaluated for its potency toward cyclin-dependent protein kinases [9] and diversely substituted 3-arylaminomethylene-indolin-2-ones were described as VEGFR [10], Trk A [11] or CDK inhibitors $[12,13]$. However, none of the described compounds was functionalized with an amino acid group (Fig. 2).

In this paper, the synthesis of indolin-2-ones substituted in the 3 position with an aminomethylene group bearing different amino acid moieties is described (compounds 4, 12 and 13; Fig. 2). The amino acid moiety could reinforce the hydrogen bond net inside the active site of the target(s) enzyme(s). To get an insight into the substitution pattern required for the best biological potencies, the side chains are either flexible (compound 4) or more rigid and differently oriented (compounds $12,13)$.

\section{Chemistry}

The synthesis of indolin-2-one derivative 4 bearing a lysine moiety in the 3 position was achieved in three steps from the commercially available isatine (Scheme 1). 3-Chloromethylene-indolin-2-one 1 was prepared as a mixture of $\mathrm{Z}, \mathrm{E}$ isomers in $51 \%$ yield by a Wittig reaction performed with (chloromethyl)triphenylphosphonium iodide in THF in the presence of $n$-butyllithium. The dichlorinated product 2, which could 


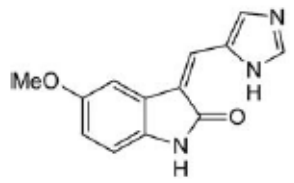

SU9516

CDK-2/cyclin A inhibito<smiles>Cc1cc(C)c(C=C2C(=O)Nc3ccccc32)[nH]1</smiles>

SU5416

VEGFR-2 inhibitor Phase III clinical trials

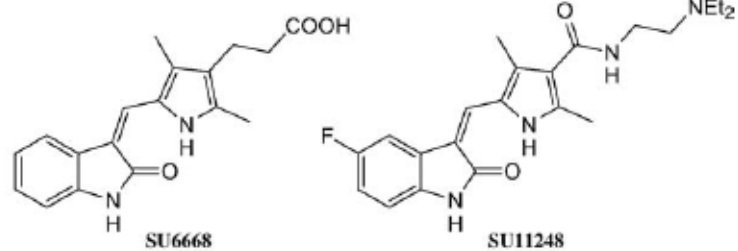

SU6668

VEGFR-2, PDGFR- $\beta$, FGFR-1 inhibitor Phase II clinical trials

VEGFR- 2 and PDGFR- $\beta$ inhibitor Phase I clinical trials
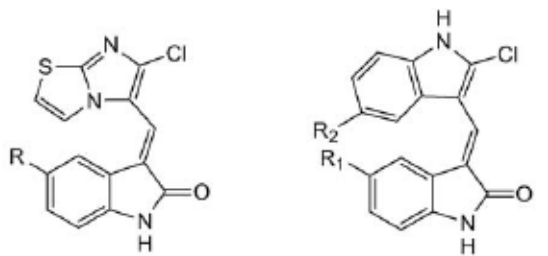

Compound A

$$
\text { CDK-1/cyclin B inhibitors }
$$

Fig. 1.

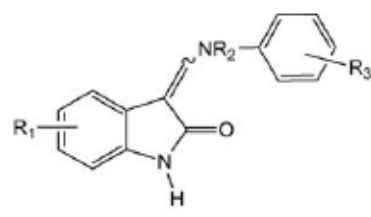

3-arylaminomethylene-indolin-2-ones<smiles>N[C@@H](Cl)CCCCNC=C1C(=O)Nc2ccccc21</smiles><smiles>N[C@@H](C(=O)O)c1cccc(NN=C2C(=O)Nc3ccccc32)c1</smiles><smiles>CNC=C1C(=O)Nc2ccccc21</smiles>

3- $\mathrm{N}$-methylaminomethylene-indolin-2-one<smiles>N[C@@H](Cc1ccc(NN=C2C(=O)Nc3ccccc32)cc1)C(=O)O</smiles>

Fig. 2.

formed by the use of a phosphonium salt excess ( 3 equivalents), was also isolated in $4 \%$ yield (Scheme 1). Compounds 1 and 2 have already been described in the literature via other pathways [14-17]. Compound $1 \mathrm{Z} / \mathrm{E}$ isomeric ratio (70/30) was determined from the ${ }^{1} \mathrm{H}$ NMR spectrum on the $\mathrm{H}_{6}$ signals at 7.24 and $7.32 \mathrm{ppm}$, respectively, since the signals of the vinylic protons were superposed upon other signals. Despite numerous purification trials (crystallization and chromatographic methods including HPLC), the isomers could not be cleanly separated, only small amounts of $1 \mathrm{Z}$ were obtained by crystallization in EtOAc. When the synthesis of compound 4 was tried by reaction of 1 equivalent of L-lysine and 1 equivalent of compound 1 in the presence of $\mathrm{NaOH}$ in metha- nol, the single product identified was the "dimer" 3 resulting from the displacement of the vinylic chlorine atoms of two indolin-2-one derivatives 1 by both lysine $\mathrm{NH} \varepsilon$ and $\mathrm{NH}_{2} \alpha$ functions (Scheme 1). The complexity of the ${ }^{1} \mathrm{H}$ NMR spectrum of 3 is due to the presence of four diastereoisomers: (3Z, $\left.3^{\prime} \mathrm{Z}\right)$, (3Z, $\left.3^{\prime} \mathrm{E}\right),\left(3 \mathrm{E}, 3^{\prime} \mathrm{E}\right)$ and (3E, $\left.3^{\prime} \mathrm{Z}\right)$ (Scheme 1). All $\mathrm{NH}_{\text {indolic }}$ as well as two $\mathrm{H}_{\text {vinylic }}$ signals could be easily distinguished on the spectrum. The integral values of these two $\mathrm{H}_{\text {vinylic }}$ signals were identical to those of the major $\mathrm{NH}_{\text {indolic }}$ signals at 10.17 and $10.23 \mathrm{ppm}$. On this basis, the diastereoisomeric ratio was $35 / 35 / 15 / 15$. The dimeric structure was confirmed by HRMS. To limit the formation of this by-product, the reaction was carried out in the same conditions with 2 equivalents of $L_{-}$ 

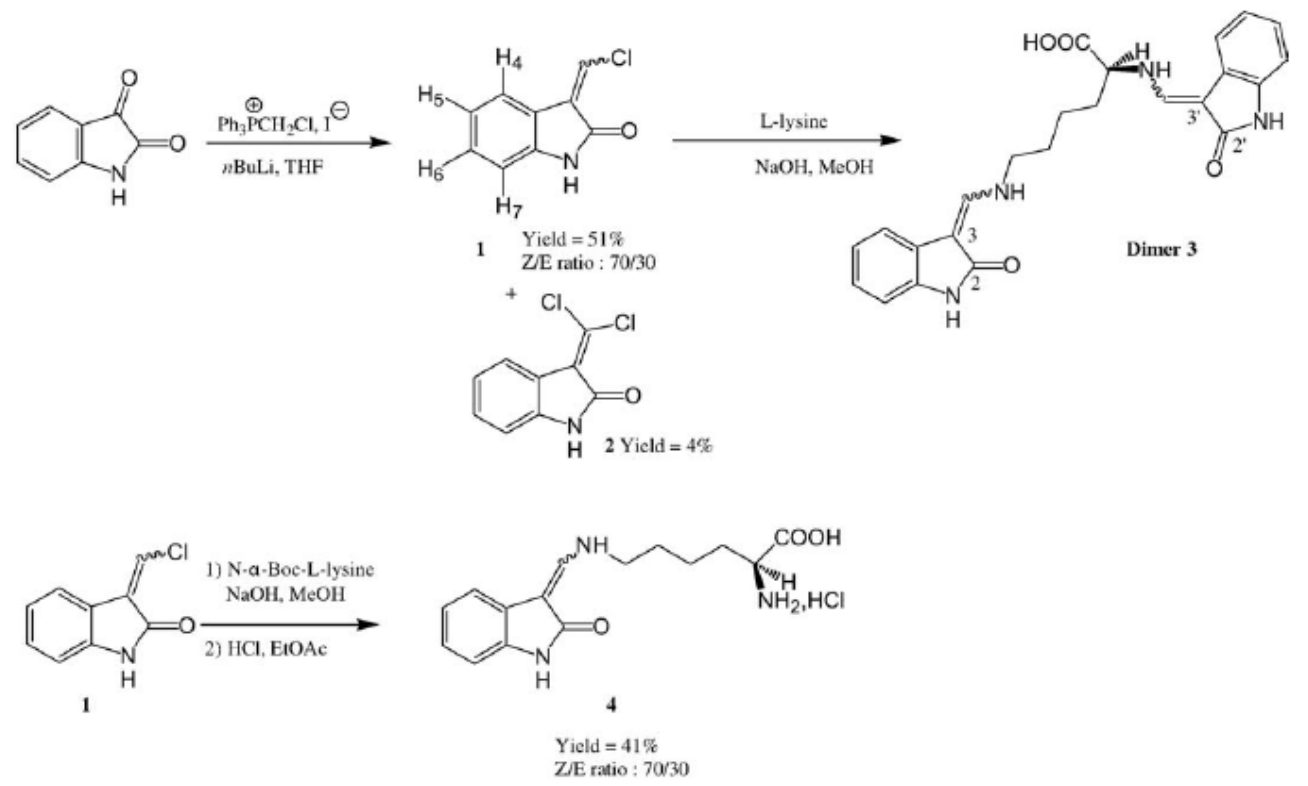

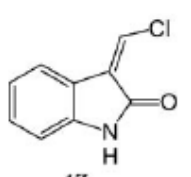

$1 \mathrm{z}$

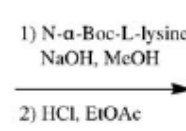

2) HCl, EIOAc

(E)-3-methoxymethylene-indoline-2-one
Yield $=28 \%$

Scheme 1.

lysine and 1 equivalent of compound 1 . Under these conditions, compound 4 was only obtained as traces. Compound 4 was finally obtained in $41 \%$ yield by reaction of 1 and $N-(\alpha)$ tert-butoxycarbonyl-L-lysine in the presence of $\mathrm{NaOH}$ in methanol, followed by the removal of the tert-butoxycarbonyl protective group in an acidic medium. Compound 4 was obtained as a mixture $(70 / 30)$ of $\mathrm{Z} / \mathrm{E}$ isomers. The $\mathrm{Z} / \mathrm{E}$ isomeric ratio was determined from the ${ }^{1} \mathrm{H}$ NMR spectrum on the signals of the vinylic protons respectively at 7.93 and $7.43 \mathrm{ppm}$. The coupling reaction was also carried out in the same conditions with a small quantity of $1 \mathrm{Z}$ (Scheme 1). Surprisingly, the only product obtained was the (E)-3-methoxymethylene-indolin-2-one 5 [15] formed by a side reaction with the solvent $\mathrm{MeOH}$ (Scheme 1). In contrast with what was obtained with the mixture of $\mathrm{Z} / \mathrm{E}$ isomers of 1 , when starting from the $\mathrm{Z}$ isomer no traces of compound 4 was detected. It could be possible that, in the case of the $\mathrm{Z} / \mathrm{E}$ mixture, only the $\mathrm{E}$ isomer has reacted with the $N$ - $(\alpha)$-tert-butoxycarbonyl-L-lysine to give 4 as a mixture of $\mathrm{Z} / \mathrm{E}$ isomers. This result could also be explained by isomerization of vinyl chloride and/or the resulted enamine.

For the synthesis of compounds 12 and 13 (Fig. 2), the required intermediates $\mathbf{8}$ and $\mathbf{1 1}$ were prepared respectively from D-phenylalanine and L-phenylglycine according to the procedure described for the synthesis of $p$-amino-L-phenylalanine (Scheme 2) [18,19]. First, different conditions for the nitration of L-phenylalanine have been tried to prepare the enantiomer of compound 8 . However, in contrast with what was described in the literature [20], the required $p$-nitro-L-phenylalanine was never obtained. When the nitration step was carried out on Dphenylalanine, $p$-nitro-D-phenylalanine 6 was obtained in $16 \%$ yield. The nitration leading to 6 and 9 derivatives was performed in the presence of a mixture of concentrated $\mathrm{HNO}_{3}$ and $\mathrm{H}_{2} \mathrm{SO}_{4}$. The $\alpha$-amino function was further protected using ditert-butyl dicarbonate in the presence of saturated aqueous $\mathrm{NaHCO}_{3}$. The amino intermediates 8 and 11 were finally obtained by catalytic hydrogenation of the corresponding protected nitro derivatives 7 and $\mathbf{1 0}$. The physical properties, including $[\alpha]_{D}$ values and spectral data of $6,7,8$ were identical to those described in the literature for their enantiomers [18, 20]. Several batches of these compounds were prepared; however, in all the cases, the $[\alpha]_{D}$ values were opposite to those expected on the basis of the literature data. For compounds $\mathbf{9}$, 10 and 11 , the physical properties and spectral data were in accordance with those already described in the literature for the corresponding enantiomer (compound 9) [21] or racemate (compound 10 and 11) [22].

Compounds 12 and 13 , substituted in the 3 position by amino acid moieties containing a phenyl ring, were obtained using the same procedure as described above for compound $\mathbf{4}$ (Scheme 3).

In these conditions, compound 12 was obtained as a mixture $(85 / 15)$ of $\mathrm{Z} / \mathrm{E}$ isomers in $29 \%$ yield whereas compound 13 was obtained as a mixture $(80 / 20)$ of $Z / E$ isomers in $52 \%$ yield. 

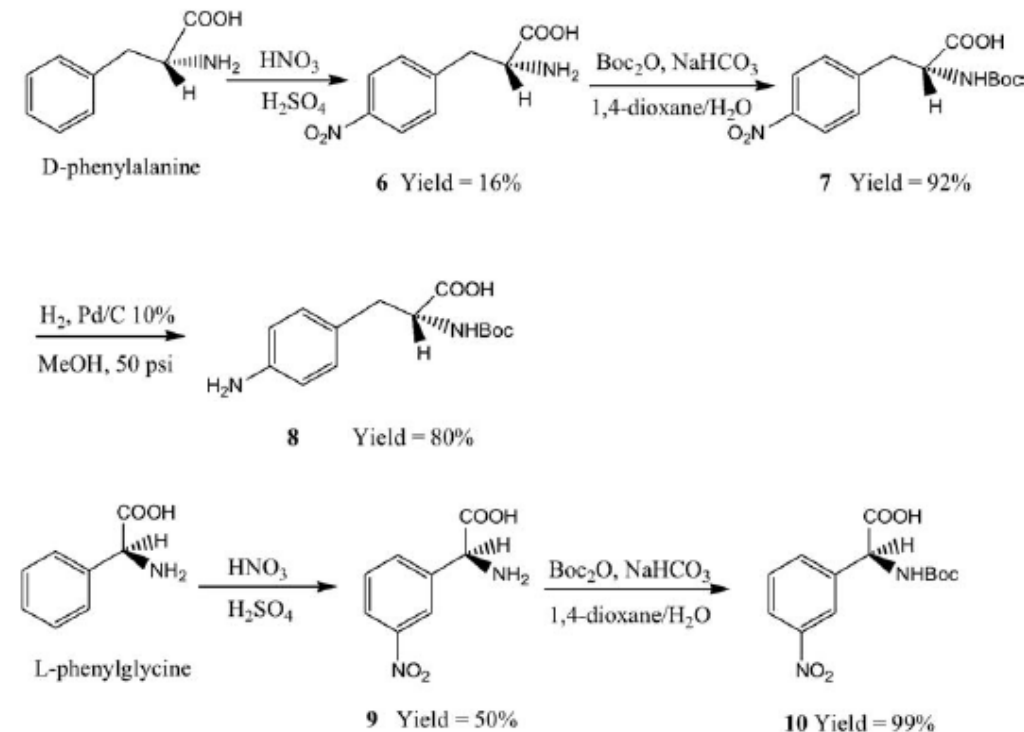

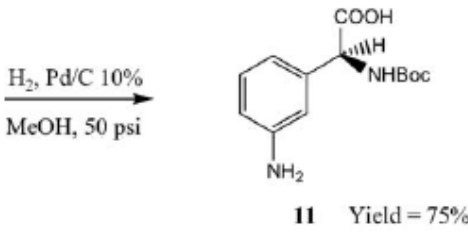

Scheme 2 .

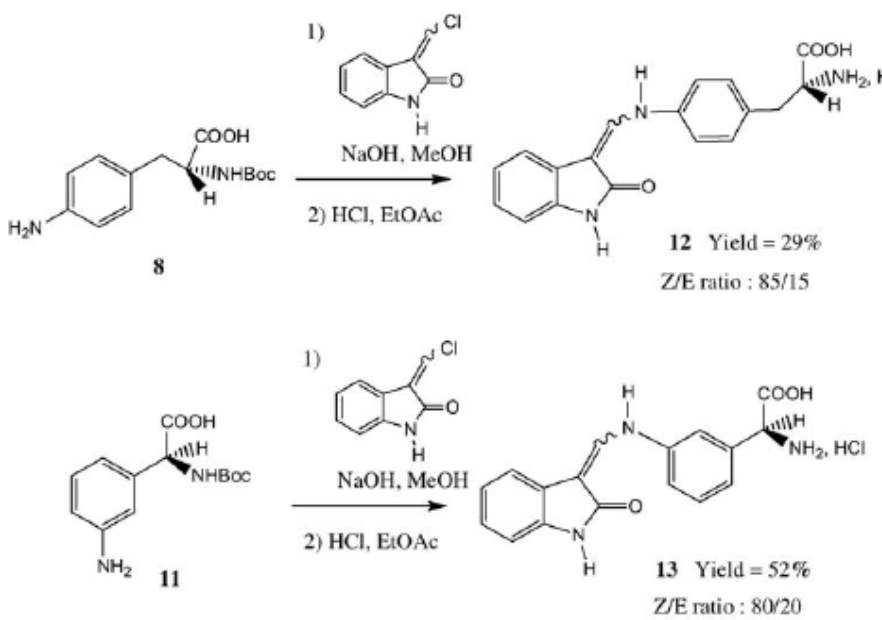

Scheme 3 .

The $\mathrm{Z} / \mathrm{E}$ isomeric ratio for compound 12 was determined from the ${ }^{1} \mathrm{H}$ NMR spectrum on the signals of the vinylic protons respectively at 8.63 and $7.79 \mathrm{ppm}$ and for compound 13 , on the signals of the vinylic protons at 8.65 and $7.74 \mathrm{ppm}$. The $\mathrm{Z} / \mathrm{E}$ isomeric ratios of compounds 4,12 and 13 were evaluated by quantum semi-empirical calculations, using Ampac8.0 program [23], on both isomers global minima geometries found previously by conformational analysis using Macromodel 7.0 program [24]. The comparison of the $E_{\mathrm{a}}$ activation energy (en- ergy difference between the reactants and the transition state) of $Z$ and $E$ isomers for compounds 4, 12 and 13 showed that the $\mathrm{Z}$ configuration is the major one (Table 1). The results showed that, for these three compounds, the $\mathrm{Z}$ isomer was stabilized by an intramolecular hydrogen bond (black lines, Fig. 3) between the NH hydrogen and the oxygen of the oxindole carbonyl group. For compound 4, the folding of the flexible side chain was stabilized by an additional hydrogen bond between the $\alpha$-amino function and the oxygen atom of the oxi- 
Table 1

Computational results of $\mathrm{Z} / \mathrm{E}$ isomers for compounds 4,12 and 13

\begin{tabular}{|c|c|c|c|}
\hline & $4 Z$ & & $4 \mathrm{E}$ \\
\hline$E_{\mathrm{a}}$ activational energy $\left(\mathrm{kcal} \mathrm{mol}^{-1}\right)$ & 20.0 & & 23.0 \\
\hline$E_{\mathrm{a}}(\mathrm{Z})-E_{\mathrm{a}}(\mathrm{E})\left(\mathrm{kcal} \mathrm{mol}^{-1}\right)$ & & 3.0 & \\
\hline Theoretical ratio $\mathrm{Z} / \mathrm{E}$ & 99.0 & & 1.0 \\
\hline \multirow[t]{2}{*}{ Experimental ratio Z/E } & 70.0 & & 30.0 \\
\hline & $12 Z$ & & $12 \mathrm{E}$ \\
\hline$E_{\mathrm{a}}$ activational energy $\left(\mathrm{kcal} \mathrm{mol}^{-1}\right)$ & 63.0 & & 66.0 \\
\hline$E_{\mathrm{a}}(\mathrm{Z})-E_{\mathrm{a}}(\mathrm{E})\left(\mathrm{kcal} \mathrm{mol}^{-1}\right)$ & & 3.0 & \\
\hline Theoretical ratio $\mathrm{Z} / \mathrm{E}$ & 99.0 & & 1.0 \\
\hline \multirow[t]{2}{*}{ Experimental ratio $\mathrm{Z} / \mathrm{E}$} & 85.0 & & 15.0 \\
\hline & $13 Z$ & & $13 \mathrm{E}$ \\
\hline$E_{\mathrm{a}}$ activational energy $\left(\mathrm{kcal} \mathrm{mol}^{-1}\right)$ & 72.0 & & 75.0 \\
\hline$E_{\mathrm{a}}(\mathrm{Z})-E_{\mathrm{a}}(\mathrm{E})\left(\mathrm{kcal} \mathrm{mol}^{-1}\right)$ & & 3.0 & \\
\hline Theoretical ratio $\mathrm{Z} / \mathrm{E}$ & 99.0 & & 1.0 \\
\hline Experimental ratio Z/E & 80.0 & & 20.0 \\
\hline
\end{tabular}

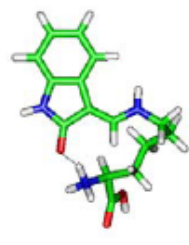

$4 \mathrm{E}$

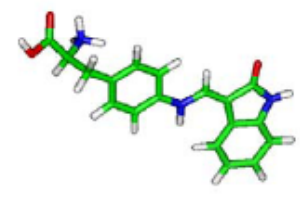

12E

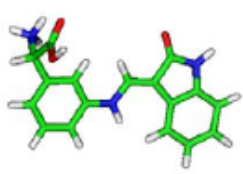

13E

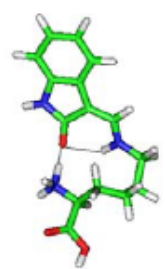

$4 Z$

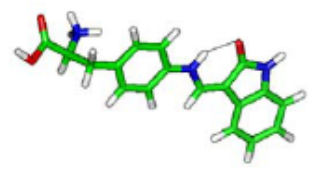

$12 Z$

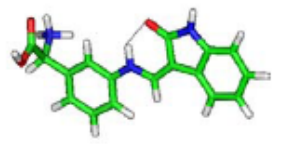

$13 Z$
Fig. 3.

ndole moiety. Moreover, the conformation around the $\mathrm{CH}$ vinylic-NH bond was also characterized by ${ }^{1} \mathrm{H}$ NMR spectroscopy. Arising from restricted rotation around this bond, the signals of the vinylic protons were doublets (compounds 4 , 12 and 13) and the NH signals were doublets for compounds 12 and 13 and a doubled triplet for compound 4 with a $J_{\mathrm{CH}-\mathrm{NH}}$ coupling constant of $12.0-13.5 \mathrm{~Hz}$, which is typical of an anti conformation [25].

\section{Biological activities}

A preliminary evaluation of the antiproliferative activities of compounds 4,12 and 13 was performed in vitro by two fluoro- metric assays: Resazurin reduction test (RRT) and Hoechst 33342 dye DNA assay [26] in a panel of human solid cancer cell lines (PC 3: prostatic adenocarcinoma, DLD-1: colon carcinoma, MCF-7: breast adenocarcinoma, M4Beu: melanoma teratocarcinoma, A549: lung carcinoma, PA 1: ovarian carcinoma), and healthy cell lines (a murine fibroblast cell line L929 and a human fibroblast primary culture). Compound 12 and 13 were inactive against the cell lines tested. Only compound 4, bearing a flexible side chain, showed antiproliferative activities. This compound was selective toward some of the cell lines tested since it exhibited cytotoxicity only against DLD-1 $\left(\mathrm{IC}_{50}=10 \mu \mathrm{M}\right)$, PA-1 $\left(\mathrm{IC}_{50}=15 \mu \mathrm{M}\right), \mathrm{L} 929\left(\mathrm{IC}_{50}=17 \mu \mathrm{M}\right)$ and fibroblast $\left(\mathrm{IC}_{50}=14 \mu \mathrm{M}\right)$ cell lines.

In conclusion, a convenient method for the synthesis of substituted indolin-2-ones bearing different amino acid moieties in the 3 position is described. The antiproliferative activities of these compounds have shown that a better pharmaceutical profile is obtained with a flexible side chain which allows the folding of this chain. The inhibitory activities of compound 4 toward various kinases and the synthesis of compound 4 analogues are currently under investigation in our laboratory.

\section{Experimental}

\subsection{Chemistry}

IR spectra were recorded on a Perkin-Elmer 881 spectrometer $\left(v\right.$ in $\left.\mathrm{cm}^{-1}\right)$. NMR spectra were performed on a Bruker AVANCE $400\left({ }^{1} \mathrm{H}: 400 \mathrm{MHz},{ }^{13} \mathrm{C}: 100 \mathrm{MHz}\right.$ ) (chemical shifts $\delta$ in ppm, the following abbreviations are used: singlet (s), doublet (d), triplet (t), doubled triplet (dt), doubled doublet (dd), doubled doubled doublet (ddd), multiplet (m), broad signal (br s), tertiary carbons ( $\mathrm{C}$ tert), quatemary carbons ( $\mathrm{C}$ quat.). Mass spectra (ES) were determined on a high resolution Waters Micro Q-toff apparatus. Chromatographic purifications were performed by flash silica gel Geduran SI 60 (Merck) $0.040-0.063 \mathrm{~mm}$ column chromatography. For purity tests, TLC was performed on fluorescent silica gel plates (60 F254 from Merck).

\subsection{1. (Z/E)-3-chloromethylene-indolin-2-one 1 and 3,3-dichloromethylene-indolin-2-one 2}

A solution of butyllithium (1.6 M in hexane, $1.8 \mathrm{ml}$, $2.9 \mathrm{mmol}$ ) was added to a suspension of (chloromethyl)triphenylphosphonium iodide $(1.3 \mathrm{~g}, 3.06 \mathrm{mmol})$ in THF $(20 \mathrm{ml})$. The mixture was stirred at room temperature for $1 \mathrm{~h}$ before cooling to $-10{ }^{\circ} \mathrm{C}$ and addition of a solution of isatine (150 mg, $1.02 \mathrm{mmol})$ in THF $(20 \mathrm{ml})$. The mixture was stirred at $-10^{\circ} \mathrm{C}$ for $1 \mathrm{~h}$ before addition of brine. After extraction with EtOAc, the combined organic phases were dried over $\mathrm{MgSO}_{4}$, evaporated and the residue was purified by chromatography (eluent cyclohexane/EtOAc 80:20) to give two products. Compound 2 ( $9 \mathrm{mg}, 0.04 \mathrm{mmol}, 4 \%$ yield) and a mixture of Z/E 1 (93 mg, $0.52 \mathrm{mmol}, 51 \%$ yield) were isolated as yellow powders. These compounds have already been described in the literature [14-17]. 
Compound 1: ${ }^{1} \mathrm{H}$ NMR spectrum of the diastereoisomeric mixture (400 MHz, DMSO- $\left.d_{6}\right): 6.83(\mathrm{~d}, J=7.5 \mathrm{~Hz}, 1 \mathrm{H}, \mathrm{Z}$ isomer), 6.88 (d, $J=7.5 \mathrm{~Hz}, 1 \mathrm{H}, \mathrm{E}$ isomer), 6.96 (t, $J=7.5 \mathrm{~Hz}$, $1 \mathrm{H}, \mathrm{Z}$ isomer), 7.03 (t, $J=7.5 \mathrm{~Hz}, 1 \mathrm{H}, \mathrm{E}$ isomer), 7.24 (dt, $J_{I}$ $=7.5 \mathrm{~Hz}, J_{2}=1.0 \mathrm{~Hz}, 1 \mathrm{H}, \mathrm{Z}$ isomer $), 7.32\left(\mathrm{dt}, J_{I}=7.5 \mathrm{~Hz}, J_{2}\right.$ $=1.0 \mathrm{~Hz}, 1 \mathrm{H}, \mathrm{E}$ isomer $), 7.58\left(\mathrm{~s}, 1 \mathrm{H}, \mathrm{H}_{\text {vinylic }}\right.$, $\mathrm{E}$ isomer $), 7.60$ (d, $J=7.5 \mathrm{~Hz}, 1 \mathrm{H}, \mathrm{Z}$ isomer), $7.88(\mathrm{~d}, J=7.5 \mathrm{~Hz}, 1 \mathrm{H}, \mathrm{E}$ isomer), $7.88\left(\mathrm{~s}, 1 \mathrm{H}, \mathrm{H}_{\text {vinylic }}, \mathrm{Z}\right.$ isomer), $10.64(\mathrm{~s}, 1 \mathrm{H}, \mathrm{NH}, \mathrm{Z}$ isomer), 10.67 (s, 1H, NH, E isomer).

\subsubsection{Diastereoisomeric mixture of dimer 3}

To a solution of $1(90 \mathrm{mg}, 0.5 \mathrm{mmol})$ in $\mathrm{MeOH}(5 \mathrm{ml})$ were added successively, L-lysine $(73 \mathrm{mg}, 0.5 \mathrm{mmol})$ and an aqueous $1 \mathrm{~N} \mathrm{NaOH}$ solution $(0.5 \mathrm{ml})$. After stirring for 4 hours at room temperature, the reaction mixture was neutralized by addition of $\mathrm{HCl}(1 \mathrm{~N})$ before extraction with EtOAc. The organic phases were dried over $\mathrm{MgSO}_{4}$ and concentrated under vacuum to give 3 (34 mg, $0.079 \mathrm{mmol}, 32 \%$ yield) as a green amorphous solid. IR $(\mathrm{NaCl}) v_{\mathrm{NH}}$, OH $3671-3044 \mathrm{~cm}^{-1} v_{\mathrm{C}=\mathrm{O}}$ $1730 \mathrm{~cm}^{-1} v_{\mathrm{C}=\mathrm{O}} 1671 \mathrm{~cm}^{-1} v_{\mathrm{C}=\mathrm{C}} 1606 \mathrm{~cm}^{-1}$. HRMS (ES) calcd for $\mathrm{C}_{24} \mathrm{H}_{25} \mathrm{~N}_{4} \mathrm{O}_{4}[\mathrm{M}+\mathrm{H}]^{+}: 433.1876$, found 433.1889 . ${ }^{1} \mathrm{H}$ NMR spectrum of the mixture of four diastereoisomers (400 MHz, DMSO- $\left.d_{6}\right): 1.35-1.46\left(\mathrm{~m}, \mathrm{CH}_{2}\right.$ lys $), 1.55-1.70$ (m, $\mathrm{CH}_{2}$ lys $), 1.78-1.98$ (m, $\mathrm{CH}_{2}$ lys), 3.35-3.48 (m, $\mathrm{CH}_{2}$ lys $), 4.06-$ $4.15\left(\mathrm{~m}, \mathrm{CH}_{\alpha}\right), 6.76-7.01(\mathrm{~m}), 7.26-7.35(\mathrm{~m}), 7.38-7.50(\mathrm{~m})$, $7.55-7.68(\mathrm{~m}), 7.92$ (d, $\left.J=13.5 \mathrm{~Hz}, \mathrm{H}_{\text {vinylic }}\right), 7.93$ (d, $\left.J=13.5 \mathrm{~Hz}, \mathrm{H}_{\text {vinylic }}\right), 8.82\left(\mathrm{dt}, J_{I}=13.0 \mathrm{~Hz}, J_{2}=6.0 \mathrm{~Hz}\right.$, $\mathrm{NH}_{\text {vinylic }}$ ), 8.99-9.06 (m, $\left.\mathrm{NH}_{\text {vinylic }}\right), 9.91$ (s, $\left.\mathrm{NH}_{\text {indolic }}\right), 9.96$ (s, $\mathrm{NH}_{\text {indolic }}$ ), 10.17 (br s, $\mathrm{NH}_{\text {indolic }}$ ), 10.23 (s, $\mathrm{NH}_{\text {indolic }}$ ). The signal of the carboxylic acid proton is not visible on the spectrum.

\subsubsection{Typical coupling and deprotection procedure for the preparation of compounds 4, 12 and 13}

An aqueous $1 \mathrm{~N} \mathrm{NaOH}$ solution $(0.35 \mathrm{ml})$ was added to a solution of $\mathrm{N}$ - $(\alpha)$-Boc-amino acids $(0.35 \mathrm{mmol})$ in $\mathrm{MeOH}$ $(3 \mathrm{ml})$ before adding a solution of $(\mathrm{Z} / \mathrm{E})-3$-chloromethyleneindolin-2-one $1(0.35 \mathrm{mmol})$ in $\mathrm{MeOH}(3 \mathrm{ml})$. After stirring at room temperature for 24 hours, the reaction mixture was neutralized by addition of $\mathrm{HCl}(1 \mathrm{~N})$ before extraction with EtOAc. The organic phases were dried over $\mathrm{MgSO}_{4}$ and concentrated under vacuum. EtOAc $(4.2 \mathrm{ml})$ and $\mathrm{HCl} 3 \mathrm{M}$ $(1.26 \mathrm{ml})$ were added to the residue. The mixture was stirred for 4 hours at $50^{\circ} \mathrm{C}$. The required compounds were isolated by filtration of the solid obtained after evaporation and addition of EtOAc.

(Z/E, S)-3-(5-amino-5-carboxypentylaminomethylene)-indolin-2-one 4 : yellow solid. IR (KBr) $v_{\mathrm{OH}, \mathrm{NH}} 3660-3170 \mathrm{~cm}^{-1}, \mathrm{v}$ $\mathrm{C}=\mathrm{O} 1735 \mathrm{~cm}^{-1}, v_{\mathrm{C}=\mathrm{O}} 1653 \mathrm{~cm}^{-1} v_{\mathrm{C}=\mathrm{C}} 1615 \mathrm{~cm}^{-1}$. HRMS (ES) calcd for $\mathrm{C}_{15} \mathrm{H}_{19} \mathrm{~N}_{3} \mathrm{NaO}_{3}[\mathrm{M}+\mathrm{Na}]^{+}: 312.1324$, found 312.1342 . NMR of the major $\mathrm{Z}$ isomer: ${ }^{1} \mathrm{H}$ NMR $\left(400 \mathrm{MHz}, \mathrm{DMSO}-d_{6}\right)$ : $1.33-1.55$ (m, 2H, CH $\mathrm{CH}_{2}$ ), $1.58-1.69$ ( $\mathrm{m}, 2 \mathrm{H}, \mathrm{CH}_{2}$ lys), $1.78-$ 1.92 (m, 2H, $\mathrm{CH}_{2}$ lys), 3.34-3.44 (m, 2H, $\mathrm{CH}_{2}$ lys), 3.92-3.99 $\left(\mathrm{m}, 1 \mathrm{H}, \mathrm{CH}_{\alpha}\right), 6.78-6.93(\mathrm{~m}, 3 \mathrm{H}), 7.31$ (d, $\left.J=8.0 \mathrm{~Hz}, 1 \mathrm{H}\right), 7.93$ (d, $J=13.5 \mathrm{~Hz}, 1 \mathrm{H}, \mathrm{H}_{\text {vinylic }}$ ), 8.29-8.41 (br s, $3 \mathrm{H}, \mathrm{NH}_{3}{ }^{+}$), 8.79 (dt, $J_{l}=13.5 \mathrm{~Hz}, J_{2}=6.5 \mathrm{~Hz}, 1 \mathrm{H}, \mathrm{NH}_{\text {vinylic }}$ ), $10.20(\mathrm{~s}, 1 \mathrm{H}$, $\mathrm{NH}_{\text {indolic }}$ ). The signal of the carboxylic acid proton is not visible on the spectrum. ${ }^{13} \mathrm{C}$ NMR (100 MHz, DMSO- $\left.d_{6}\right): 21.3,29.5$, $30.2,47.9\left(\mathrm{CH}_{2}\right.$ lys $), 51.7\left(\mathrm{CH}_{\text {lys }}\right), 94.3,125.3,135.5$ ( $\left.\mathrm{C}_{\text {arom. }}\right)$, $108.6,114.9,119.7,121.9,147.8\left(\mathrm{CH}_{\text {arom }}\right), 169.5,170.9$ $(\mathrm{C}=\mathrm{O})$.

\subsection{4. m-Nitro-L-phenylglycine 9}

At $0{ }^{\circ} \mathrm{C},(\mathrm{S})-(+)$-phenylglycine $(1 \mathrm{~g}, 6.6 \mathrm{mmol})$ was added to a mixture of concentrated $\mathrm{H}_{2} \mathrm{SO}_{4}(1 \mathrm{ml})$ and fuming $\mathrm{HNO}_{3}$ $(1 \mathrm{ml})$. The reaction mixture was stirred for $1 \mathrm{~h}$ at $0{ }^{\circ} \mathrm{C}$ then $30 \mathrm{~min}$. at room temperature before hydrolysis with cold water $(20 \mathrm{ml})$. The $\mathrm{pH}$ was adjusted to $\mathrm{pH} 9$ by addition of an aqueous solution of $4 \mathrm{M} \mathrm{NH}_{4} \mathrm{OH}$. The resulting mixture was stirred at $4{ }^{\circ} \mathrm{C}$ for $96 \mathrm{~h}$, compound 9 was isolated by filtration. After washing with cold water, compound 9 was isolated (647 mg, $3.3 \mathrm{mmol}, 50 \%$ yield) as a yellow powder: m.p. $160{ }^{\circ} \mathrm{C} .[\alpha]_{\mathrm{D}}^{25}=+100(c=0.66, \mathrm{HCl} 1 \mathrm{M})$, Literature value for the corresponding enantiomer $[\alpha]_{\mathrm{D}}^{25}=-89.5(c=0.8$, aq. $\mathrm{HCl})$ [21]. IR (KBr) $v_{\mathrm{NH}}$ OH $3639-3267 \quad \mathrm{~cm}^{-1} \quad v_{\mathrm{C}=\mathrm{O}}$ $1682 \mathrm{~cm}^{-1} v_{\mathrm{C}=\mathrm{C}} 1623 \mathrm{~cm}^{-1}$. ${ }^{1} \mathrm{H}\left(400 \mathrm{MHz}\right.$, DMSO- $\left.d_{6}\right): 4.50$ (s, $1 \mathrm{H}, \mathrm{H \alpha}$ ), 7.65 (t, $J=8.0 \mathrm{~Hz}, 1 \mathrm{H}) .7 .87$ (d, $J=7.5 \mathrm{~Hz}, 1 \mathrm{H})$, $8.16(\mathrm{~d}, J=8.0 \mathrm{~Hz}, 1 \mathrm{H}), 8.34(\mathrm{~s}, 1 \mathrm{H})$. Due to the insolubility of compound 9 , the ${ }^{13} \mathrm{C}$ NMR spectrum could not be recorded.

\subsection{5. $N_{a}$-Boc-m-nitro-L-phenylglycine 10}

At $0{ }^{\circ} \mathrm{C}$, saturated aqueous $\mathrm{NaHCO}_{3}(1.16 \mathrm{ml})$ and $\mathrm{Boc}_{2} \mathrm{O}$ $(0.43 \mathrm{ml}, 2.04 \mathrm{mmol})$ were added to a solution of $9(200 \mathrm{mg}$, $1.02 \mathrm{mmol})$ in 1,4-dioxane $(3.4 \mathrm{ml})$ and water $(2.3 \mathrm{ml})$. The mixture was stirred at room temperature for $24 \mathrm{~h}$. The $\mathrm{pH}$ was adjusted to $\mathrm{pH} \mathrm{2-3}$ by addition of $3 \mathrm{M} \mathrm{HCl}$. After extraction with EtOAc, the organic phases were dried over $\mathrm{MgSO}_{4}$ and the solvent was removed to give a residue which was purified by flash chromatography (eluent EtOAc/ $\mathrm{MeOH}$, from 10:0 to 8:2). Compound 10 was isolated $(299 \mathrm{mg}$, $1.01 \mathrm{mmol}, 99 \%$ yield) as a yellow powder: m.p. $115^{\circ} \mathrm{C}$ (dec.). $[\alpha]_{\mathrm{D}}^{25}=+90(c=1, \mathrm{MeOH})$. IR $(\mathrm{KBr}) v_{\mathrm{OH}} 3396 \mathrm{~cm}^{-1}$ $v_{\mathrm{NH}} 2980 \mathrm{~cm}^{-1} v_{\mathrm{C}=\mathrm{O}} 1683 \mathrm{~cm}^{-1} v_{\mathrm{C}=\mathrm{C}} 1605 \mathrm{~cm}^{-1}$. The spectral data $\left({ }^{1} \mathrm{H},{ }^{13} \mathrm{C}\right.$ NMR and HRMS $)$ of the corresponding racemate were already described in the literature [22].

\subsection{6. $N_{\alpha}$-Boc-m-amino-L-phenylglycine 11}

A mixture of $7(310 \mathrm{mg}, 1.05 \mathrm{mmol}), \mathrm{MeOH}(30 \mathrm{ml})$ and $10 \% \mathrm{Pd} / \mathrm{C}$ was hydrogenated at room temperature under $50 \mathrm{psi}$ for $24 \mathrm{~h}$. After filtration over Celite and washing with $\mathrm{MeOH}$, the filtrate was evaporated to give compound 11 (209 mg, $0.79 \mathrm{mmol}, 75 \%$ yield) as a yellow powder: $[\alpha]_{\mathrm{D}}^{25}=+75$ $(c=1, \mathrm{MeOH})$. IR $(\mathrm{KBr}) v_{\mathrm{OH}} 3410 \mathrm{~cm}^{-1} v_{\mathrm{NH}} 2990 \mathrm{~cm}^{-1}$ $v_{\mathrm{C}=\mathrm{O}} 1680 \mathrm{~cm}^{-1} v_{\mathrm{C}=\mathrm{C}} 1589 \mathrm{~cm}^{-1}$. The spectral data $\left({ }^{1} \mathrm{H} \mathrm{NMR}\right.$ and HRMS) of the corresponding racemate were already described in the literature [22].

\subsection{7. (Z/E, R)-3-[(4-aminoethyl-4-carboxyethyl) \\ phenylaminomethylene]-indolin-2-one 12}

Prepared according to the procedure described above for compound 4. Yellow solid, IR $(\mathrm{KBr}) \mathrm{v}_{\mathrm{NH}}, \mathrm{OH}$ 3664-3147 cm $\mathrm{cm}^{-1}, v_{\mathrm{C}=\mathrm{O}} 1737,1661 \mathrm{~cm}^{-1}, v_{\mathrm{C}=\mathrm{C}} 1610 \mathrm{~cm}^{-1}$. HRMS (ES) calcd for $\mathrm{C}_{18} \mathrm{H}_{18} \mathrm{~N}_{3} \mathrm{O}_{3}[\mathrm{M}+\mathrm{H}]^{+}: 324.1348$, found 
324.1364. NMR of the major $\mathrm{Z}$ isomer: ${ }^{1} \mathrm{H}$ NMR (400 MHz, DMSO- $d_{6}$ ): $3.06-3.17\left(\mathrm{~m}, 2 \mathrm{H}, \mathrm{CH}_{2}\right), 4.23$ (br s, $\left.1 \mathrm{H}, \mathrm{H}_{\alpha}\right), 6.88$ $(\mathrm{d}, J=7.0 \mathrm{~Hz}, 1 \mathrm{H}), 6.97\left(\mathrm{dt}, J_{I}=7.5 \mathrm{~Hz}, J_{2}=1.0 \mathrm{~Hz}, 1 \mathrm{H}\right)$, 7.05 (dt, $\left.J_{I}=7.5 \mathrm{~Hz}, J_{2}=1.0 \mathrm{~Hz}, 1 \mathrm{H}\right), 7.31(\mathrm{~d}, J=9.0 \mathrm{~Hz}$, $2 \mathrm{H}), 7.43$ (d, $J=9.0 \mathrm{~Hz}, 2 \mathrm{H}), 7.62$ (d, $J=7.5 \mathrm{~Hz}, 1 \mathrm{H}), 8.20$ 8.38 (br s, $\left.3 \mathrm{H}, \mathrm{NH}_{3}{ }^{+}\right), 8.63$ (d, $J=12.5 \mathrm{~Hz}, 1 \mathrm{H}, \mathrm{H}_{\text {vinylic }}$ ), 10.54 (s, $\left.1 \mathrm{H}, \mathrm{NH}_{\text {indolic }}\right), 10.76$ (d, $J=12.5 \mathrm{~Hz}, 1 \mathrm{H}, \mathrm{NH}_{\text {vinylic }}$ ). The signal of the carboxylic proton is not visible on the spectrum. ${ }^{13} \mathrm{C}$ NMR (100 MHz, DMSO- $\left.d_{6}\right): 35.0\left(\mathrm{CH}_{2}\right), 53.1\left(\mathrm{CH}_{\alpha}\right)$, $99.7,124.1,129.3,137.0,139.1\left(\mathrm{C}_{\text {arom }}\right), 109.1,115.9(2 \mathrm{C})$, $117.0,120.3,124.0,130.6(2 \mathrm{C}), 137.7\left(\mathrm{CH}_{\text {arom. }}\right), 169.8$, $170.3(\mathrm{C}=\mathrm{O})$.

\subsection{8. (Z/E, S)-3-[(3-aminomethyl-3-carboxymethyl) phenylaminomethylene]-indolin-2-one 13}

Prepared according to the procedure described above for compound 4. Yellow solid, IR (KBr) $v_{\mathrm{NH}}, \mathrm{OH}$ $3665-3136 \mathrm{~cm}^{-1}, v_{\mathrm{C}=\mathrm{O}} 1732,1668 \mathrm{~cm}^{-1}, v_{\mathrm{C}=\mathrm{C}} 1594 \mathrm{~cm}^{-1}$. HRMS (ES) calcd for $\mathrm{C}_{17} \mathrm{H}_{16} \mathrm{~N}_{3} \mathrm{O}_{3}[\mathrm{M}+\mathrm{H}]^{+} 310.1192$, found 310.1205. NMR of the major $\mathrm{Z}$ isomer: ${ }^{1} \mathrm{H}$ NMR $(400 \mathrm{MHz}$, DMSO- $d_{6}$ ): 5.13 (br s, $1 \mathrm{H}, \mathrm{H} \alpha$ ), 6.88-6.95 (m, 1H), 6.97-7.00 $(\mathrm{m}, 1 \mathrm{H}), 7.06-7.10(\mathrm{~m}, 1 \mathrm{H}), 7.20-7.22(\mathrm{~m}, 1 \mathrm{H}), 7.50-7.55(\mathrm{~m}$, $2 \mathrm{H}), 7.58-7.63(\mathrm{~m}, 2 \mathrm{H}), 8.65$ (d, $J=12.0 \mathrm{~Hz}, 1 \mathrm{H}, \mathrm{H}_{\text {vinylic }}$ ), $8.81-8.92\left(\mathrm{~m}, 4 \mathrm{H}, \mathrm{NH}_{3}{ }^{+}, \mathrm{OH}\right), 10.61\left(\mathrm{~s}, 1 \mathrm{H}, \mathrm{NH}_{\text {indolic }}\right), 10.86$ (d, $\left.J=12.5 \mathrm{~Hz}, 1 \mathrm{H}, \mathrm{NH}_{\text {vinylic }}\right) .{ }^{13} \mathrm{C}$ NMR $(100 \mathrm{MHz}$, DMSO$\left.d_{6}\right)$ : $55.3\left(\mathrm{CH}_{\alpha}\right), 100.3,123.9,134.6,137.1,140.3\left(\mathrm{C}_{\text {arom. }}\right)$, $109.2,115.4,116.1,117.2,120.4,122.3,124.3,130.2,137.4$ $\left(\mathrm{CH}_{\text {arom. }}\right), 169.3,169.8(\mathrm{C}=\mathrm{O})$.

\subsection{Antiproliferative activities}

\subsubsection{Cell cultures}

Stock cell cultures were maintained as monolayers in 75$\mathrm{cm}^{2}$ culture flasks in Glutamax Eagle's minimum essential medium (MEM) with Earle's salts supplemented with $10 \%$ fetal calf serum, $5 \mathrm{ml} 100 \mathrm{mM}$ sodium pyruvate, $5 \mathrm{ml}$ of $100 \times$ non-essential amino acids and $2 \mathrm{mg}$ gentamicin base. Cells were grown at $37^{\circ} \mathrm{C}$ in a humidified incubator under an atmosphere containing $5 \% \mathrm{CO}_{2}$.

\subsubsection{Survival assays}

Cells were plated at a density of $5 \times 10^{3}$ cells in $190 \mu \mathrm{l}$ culture medium in each well of 96-well microplates and were allowed to adhere for $16 \mathrm{~h}$ before treatment with tested drug. A stock solution $20 \mathrm{mM}$ of each tested drug was prepared in DMSO and kept at $-20^{\circ} \mathrm{C}$ until use. Then $50 \mu$ of each tested solution were added to the cultures. A $48 \mathrm{~h}$ continuous drug exposure protocol was used. The antiproliferative effect of the tested drug was assessed by both the resazurin reduction test and determination of DNA cellular content after cell lysis.

\subsubsection{Resazurin reduction test}

Plates were rinsed with $200 \mu \mathrm{lBS}$ at $37^{\circ} \mathrm{C}$ and emptied by overturning on absorbent toweling. Then $150 \mu \mathrm{l}$ of a $25 \mu \mathrm{g}$ $\mathrm{ml}^{-1}$ solution of resazurin in MEM without phenol red was added to each well. Plates were incubated for $1 \mathrm{~h}$ at $37{ }^{\circ} \mathrm{C}$ in a humidified atmosphere containing $5 \% \mathrm{CO}_{2}$. Fluorescence was then measured on an automated 96-well plate reader (Fluoroscan Ascent FL, Labsystem) using an excitation wavelength of $530 \mathrm{~nm}$ and an emission wavelength of $590 \mathrm{~nm}$. Under the conditions used, fluorescence was proportional to the number of living cells in the well. The $\mathrm{IC}_{50}$, defined as the drug concentration required to inhibit cell proliferation by $50 \%$, was calculated from the curve of concentration-dependent survival percentage, defined as fluorescence in experimental wells compared with fluorescence in control wells, after subtraction of the blank values.

After reading, cells were prepared for cellular DNA quantitation with Hoechst dye 3342. They were rinsed with PBS, resazurin solution was then eliminated and plates were stored at $-80^{\circ} \mathrm{C}$.

\subsubsection{Hoechst dye 3342 test}

On the day of assay, plates were thawed at room temperature for $10 \mathrm{~min} .100 \mu \mathrm{l}$ of a $0.01 \%(\mathrm{~m} / \mathrm{v})$ SDS solution in distilled water was then distributed into each well, the plates were incubated for $1 \mathrm{~h}$ at room temperature and frozen again at $-80{ }^{\circ} \mathrm{C}$ for $1 \mathrm{~h}$. After thawing, $100 \mu \mathrm{l}$ of Hoechst dye 33342 solution at $30 \mu \mathrm{g} \mathrm{ml}^{-1}$ in a hypersaline buffer (10 mM Tris$\mathrm{HCl}, \mathrm{pH} 7.4,1 \mathrm{mM}$ EDTA and $2 \mathrm{M} \mathrm{NaCl}$ ) were added to each well. The plates protected from light were incubated in this solution at room temperature for $1 \mathrm{~h}$ on a plate shaker. Fluorescence was then measured at $360 / 460 \mathrm{~nm}$ on a microplate fluorescence reader.

Under the conditions used, fluorescence was proportional to the amount of biomass and the $\mathrm{IC}_{50}$ was calculated as above.

\section{Acknowledgements}

The authors are grateful to Professor C. Barthomeuf (laboratoire de pharmacognosie-biotechnologies, UMR Inserm 484, université d'Auvergne, centre Jean-Perrin, Clermont-Ferrand) for allowing the biological assays in her laboratory.

\section{References}

[1] S. Messaoudi, M. Sancelme, V. Polard-Housset, B. Aboab, P. Moreau, M. Prudhomme, Eur. J. Med. Chem. 39 (2004) 453-458.

[2] M. Sassatelli, E. Saab, F. Anizon, M. Prudhomme, P. Moreau, Tetrahedron Lett. 45 (2004) 4827-4830.

[3] A.D. Laird, J.M. Cherrington, Expert Opin. Investig. Drugs 12 (2003) $51-64$.

[4] L. Sun, C. Liang, S. Shirazian, Y. Zhou, T. Miller, J. Cui, J.Y. Fukuda, J.-Y. Chu, A. Nematalla, X. Wang, H. Chen, A. Sistla, T.C. Luu, F. Tang, J. Wei, C. Tang, J. Med. Chem. 46 (2003) 1116-1119.

[5] P. Haluska, A.A. Adjei, Curr. Opin. Investig. Drugs 2 (2001) 280-286.

[6] L.M. Toledo, N.B. Lydon, D. Elbaum, Curr. Med. Chem. 6 (1999) 775805 .

[7] A. Andreani, A. Cavalli, M. Granaiola, A. Leoni, A. Locatelli, R. Morigi, M. Rambaldi, M. Recanatini, M. Garnier, L. Meijer, Anticancer Drug Des. 15 (2000) 447-452.

[8] D.J. Moshinsky, C.R. Bellamacina, D.C. Boisvert, P. Huang, T. Hui, J. Jancarik, S.-H. Kim, A.G. Rice, Biochem. Biophys. Res. Commun. 310 (2003) 1026-1031. 
[9] C.L. Woodard, Z. Li, A.K. Kathcart, J. Terrell, L. Gerena, M. LopezSanchez, D.E. Kyle, A.K. Bhattacharjee, D.A. Nichols, W. Ellis, S.T Prigge, J.A. Geyer, N.C. Waters, J. Med. Chem. 46 (2003) 3877-3882.

[10] S.W. Andrews, J.A. Wurster, C.E. Hull, E.M. Wang, T. Malone, WO Patent (2003) WO 03027102 Chem. Abstr. 138:287525.

[11] E.R. Wood, L. Kuyper, K.G. Petrov, R.N. Hunter III, P.A. Harris, K. Lackey, Bioorg. Med. Chem. Lett. 14 (2004) 953-957.

[12] R. Walter, W. Grell, A. Heckel, F. Himmelsbach, W. Eberlein, G. Roth, et al., WO Patent (2000) 265083 WO 0018734 Chem. Abstr. 132 265083.

[13] H.N. Bramson, J. Corona, S.T. Davis, S.H. Dickerson, M. Edelstein, S.V. Frye, R.T. Gampe Jr., P.A. Harris, A. Hassel, W.D. Holmes, R.N. Hunter, K.E. Lackey, B. Lovejoy, M.J. Luzzio, V. Montana, W.J. Rocque, D. Rusnak, L. Shewchuk, J.M. Veal, D.H. Walker, L.F. Kuyper, J. Med. Chem. 44 (2001) 4339-4358.

[14] H. Behringer, H. Weissauer, Chem. Ber. 85 (1952) 743-749.

[15] M.S. Morales-Rios, M. Garcia-Velgara, H. Cervantes-Cuevas, C. Alvarez-Cisneros, P. Joseph-Nathan, Magn. Reson. Chem. 38 (2000) 172-176.

[16] D. Borrmann, R. Wegler, Chem. Ber. 102 (1969) 64-70.
[17] D.R. Long, C.G. Richard, M.S.F. Ross, J. Heterocyclic Chem. 15 (1978) 633-634.

[18] G.J. Landis, G. Lui, J.E. Shook, H.I. Yamamura, T.F. Burks, V. Hruby, J. Med. Chem. 32 (1989) 638-643.

[19] R.N. Atkinson, L. Moore, J. Tobin, S. Bruce King, J. Org. Chem. 64 (1999) 3467-3475

[20] J.S. Davies, A.K.A. Mohammed, J. Chem. Soc. Perk. Trans. II (1984) $1723-1727$.

[21] P. Friis, A. Kjaer, Acta Chem. Scand. 17 (1963) 2391-2396.

[22] Y. Lee, A.M. Marletta, P. Martasek, L.J. Roman, B.S.S. Masters, R.B. Silverman, Bioorg. Med. Chem. 7 (1999) 1097-1104.

[23] Ampac8.0, 2000 Semichem, 7128 Summit, Shawnee, KS 66216, USA.

[24] Macromodel 7.0, Shroedinger Inc, 1500 SW First Ave. Suite 1180, Portland, OR 97201, USA.

[25] R. Quintanilla-Licea, J.F. Colunga-Valladares, A. Caballero-Quintero, C Rodriguez-Padilla, R. Tamez-Guerra, R. Gomez-Flores, N. Waksman, Molecules 7 (2002) 662-673.

[26] E. Debiton, J.-C. Madelmont, J. Legault, C. Barthomeuf, Cancer Chemother. Pharmacol. 51 (2003) 474-482. 